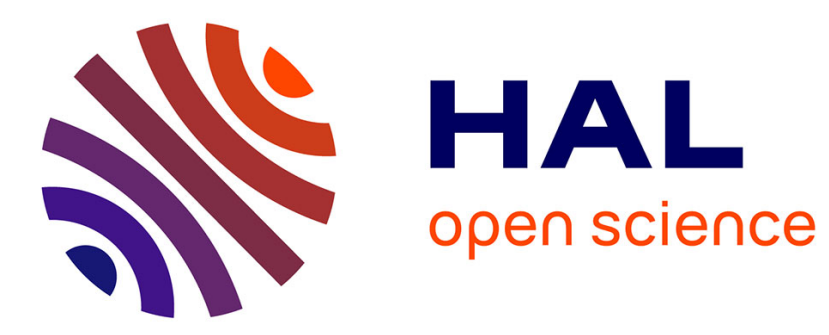

\title{
Should evidence-based medicine be considered as a truth in clinical microbiology?
}

Philippe Brouqui, Didier Raoult

\section{To cite this version:}

Philippe Brouqui, Didier Raoult. Should evidence-based medicine be considered as a truth in clinical microbiology?. International Journal of Antimicrobial Agents, 2018, 51 (2), pp.278-279. 10.1016/j.ijantimicag.2017.12.022 . hal-01780647

\section{HAL Id: hal-01780647 \\ https://hal.science/hal-01780647}

Submitted on 12 Apr 2019

HAL is a multi-disciplinary open access archive for the deposit and dissemination of scientific research documents, whether they are published or not. The documents may come from teaching and research institutions in France or abroad, or from public or private research centers.
L'archive ouverte pluridisciplinaire HAL, est destinée au dépôt et à la diffusion de documents scientifiques de niveau recherche, publiés ou non, émanant des établissements d'enseignement et de recherche français ou étrangers, des laboratoires publics ou privés. 
ic originating from, for example, soil bacteria or fungi. In the latter case, we would basically have gained a cure, enjoyed it ever so briefly, and lost it. For lugdunin and similar substances, considerably more is at stake as resistance development could make us all more vulnerable to infections than before the drug was developed.

History teaches us that all of the antibiotics mankind has ever introduced as therapeutic agents have been followed by resistance in at least some pathogens. This holds true both for strictly synthetic antibiotics and for those derived from secondary metabolites isolated from micro-organisms (e.g. lugdunin). Stating that no resistance to lugdunin has yet been encountered in any Staphylococcus aureus is therefore not reassuring. When natural antibiotics become used as drugs, the selective landscape expand radically; numerous microbiological niches become exposed, including external environments that host a much more diverse bacterial flora and hence a wider reservoir of potential resistance genes [2,3]. This development provides opportunities for the enrichment, mobilisation, horizontal transfer and fixation of genes that can provide resistance in ways not recognised before in pathogens. Overall, this is likely an important explanation as to why our arsenal of antibiotics is losing its value so rapidly.

To acquire market authorisation for any new drug, the benefits need to outweigh the risks for the patient. It seems reasonable that when evaluating an antibacterial compound which potentially may favour bacterial pathogens with increased abilities to penetrate our natural defence, one should also take into account the perceived risk for the general population. Assessing such a risk is indeed not a simple task, but this does not mean that by default it should not be considered, as this is equal to treating the risk as zero. Furthermore, leaving the design of such an assessment up to the applicant is also not advisable, as there are economic counterincentives of demonstrating risks with resistance development. Although there are recommendations both in the European and US guidelines to assess existing resistance or the potential for resistance development to novel antibacterial products, the sole purpose of these recommendations is to delineate the clinical usefulness of the drug. Hence, for antibacterial agents derived from our own defence systems, principles and guidelines to assess risks for the general population as a consequence of potential resistance development need to be developed and considered in the risk-benefit analyses in relevant regulatory frameworks.

Resistance may evolve both through mutations in pre-existing DNA or by horizontal gene transfer events. Whilst possibilities for the former are, in comparison, straightforward to explore experimentally, the latter involves a much larger number of uncertainties that are challenging to assess. This includes, for example, the prior existence of genes that could, if transferred to a pathogen, provide a resistance phenotype, their mobility potential, fitness cost, taxonomic and environmental distribution and hence the 'ecological connectivity' needed for a novel resistance gene to reach a population of pathogens [4,5]. In parallel, to better understand risks, one should also consider the anticipated exposure scenario and hence selection pressure from novel antibiotics to various microbial communities throughout its lifecycle, from production, via usage, to excretion and release into the external environment.

The depicted risk scenarios do not only apply to novel antibiotics derived from our own commensals but also the use of human antimicrobial peptides as therapeutic agents. For the latter, there has been some attention to risks for resistance development among the scientific community, but it has not yet translated into regulatory changes. It is also clear that more research is needed to understand the conditions and processes that lead to the acquisition of resistance in pathogens, as increased knowledge will enable both better risk assessments and inform preventive measures.

Given the need for novel antibiotics, exploration of our natural defence systems will likely increase our understanding of the basic biological mechanisms involved and may eventually provide society with highly valuable antibacterial agents to prevent and treat infections. However, given the potential consequences of resistance development to our own defence mechanisms, science and regulation dealing with resistance risks need to keep pace and ideally be ahead of the drug development process.

Funding: Centre for Antibiotic Resistance Research (CARe) at University of Gothenburg (Göteborg, Sweden).

Competing interests: None declared.

Ethical approval: Not required.

\section{References}

[1] Zipperer A, Konnerth MC, Laux C, Berscheid A, Janek D, Weidenmaier C, et al Human commensals producing a novel antibiotic impair pathogen colonization. Nature 2016;535:511-16.

[2] Adu-Oppong B, Gasparrini AJ, Dantas G. Genomic and functional techniques to mine the microbiome for novel antimicrobials and antimicrobial resistance genes. Ann N Y Acad Sci 2017;1388:42-58

[3] Berglund F, Nachiket MP, Österlund T, Bengtsson-Palme J, Kotsakis S, Flach CF, et al. Identification of 76 novel B1 metallo- $\beta$-lactamases through large-scale screening of genomic and metagenomic data. Microbiome 2017;5: 134.

[4] Bengtsson-Palme J, Larsson DGJ. Antibiotic resistance genes in the environment: prioritizing risks. Nat Rev Microbiol 2015;13:396.

[5] Sommer MOA, Munck C, Toft-Kehler RV, Andersson DI. Prediction of antibiotic resistance: time for a new preclinical paradigm. Nat Rev Microbiol 2017;15: 689-96.

D. G. Joakim Larsson * Centre for Antibiotic Resistance Research (CARe) at University of Gothenburg, Göteborg, Sweden

Department of Infectious Diseases, Institute of Biomedicine, Sahlgrenska Academy at University of Gothenburg, Göteborg,

Sweden

* Department of Infectious Diseases, Institute of Biomedicine, Sahlgrenska Academy at University of Gothenburg, Göteborg, Sweden. E-mail address: joakim.larsson@fysiologi.gu.se

23 October 2017

16 December 2017

\section{Should evidence-based medicine be considered as a truth in clinical microbiology?}

Sir,

Nowadays, evidence-based medicine (EBM) has gained a keen interest among doctors and decision-makers. A valuable review on 'progress in evidence-based medicine' [1] pointed out three epistemological principle bases for EBM: the practice of medicine should be based on the best available evidence; the pursuit of truth is best accomplished by evaluating the totality of the evidence and not selecting evidence that favours a particular claim; and clinical decisionmaking requires consideration of the patients' values and preferences. EBM was quickly developed and led to structuring the quality of evidence (from expert experience to randomised controlled trials) as well as to systematic reviews, meta-analyses and finally international evidence-based guidelines for clinical practice, which quickly spread all over the word through commercialised web-based decision-making applications such as UpToDate ${ }^{\circledR}$. Whilst EBM has been proven as increasing the quality of care, it is important to point out that EBM does not answer all clinical questions and that several situations are not adapted to EBM decision-making.

In the field of infectious diseases, empirical antimicrobial therapy relies on the microbial epidemiology of the environment where con- 
tamination occurred. For example, the US guidelines for empirical treatment of community-acquired pneumonia cannot be applied in Europe were pneumococcal resistance to antibiotics differs, ruling out the international usefulness of such guidelines. Another example is the occurrence of co-infection (multiple pathogens) for which empirical therapy may fail and for which aetiological diagnosis becomes mandatory. Whilst it is postulated that meta-analysis and systematic review can replace expert opinion, in the case of rare or sporadic diseases, such as $\mathrm{Q}$ fever, this is not true. Clearly the clinical experience of an individual researcher, who has seen more patients than published in the literature, brings more confident advice than the published literature itself [2]. EBM does not take into account the clinical qualities of individuals, which may be highly variable, and this is particularly true in surgery. Delay in surgery impacts the outcome in complicated infective endocarditis [3]. But the surgical training of the operator is also likely to be an important prognostic factor in surgery of complicated endocarditis. However, it would be unrealistic to assess this in a blind randomised controlled trial by comparing trained and untrained operators. Idealistic randomised controlled studies have long been debated during the 2014 deadly Ebola virus outbreak, and the humoristic 'theory of the parachute' has been highlighted on this occasion, suggesting that in some situations the 'evidence is evident' and does not support further experimentation [4]. Finally, international experts' practice of antibiotic therapy in endocarditis does not follow the guidelines, especially in life-threatening situations or due to microbiological specificities [5]. EBM has proven very useful to manage standardised and common diseases but should be used with caution in infectious diseases.
Funding: None.

Competing interests: None declared.

Ethical approval: Not required.

\section{References}

[1] Djulbegovic B, Guyatt GH. Progress in evidence-based medicine: a quarter century on. Lancet 2017;390:415-23.

[2] Raoult D. Chronic Q fever: expert opinion versus literature analysis and consensus. J Infect 2012;65:102-8.

[3] Thuny F, Beurtheret S, Mancini J, Gariboldi V, Casalta JP, Riberi A, et al. The timing of surgery influences mortality and morbidity in adults with severe complicated infective endocarditis: a propensity analysis. Eur Heart J 2011;32:2027-33.

[4] Lagier JC, Raoult D. Deadly infectious diseases such as Ebola: the parachute paradigm. Clin Microbiol Infect 2015;21:389-90.

[5] Tissot-Dupont H, Casalta JP, Gouriet F, Hubert S, Salaun E, Habib G, et al. International experts' practice in the antibiotic therapy of infective endocarditis is not following the guidelines. Clin Microbiol Infect 2017;23:736-9.

Philippe Brouqui * Didier Raoult

Institut Hospitalo-Universitaire Mediterranée Infection, Marseille, France

* Corresponding author. Institut Hospitalo-Universitaire Mediterranée Infection, 19-21 Blvd. Jean Moulin, 13005

Marseille, France.

E-mail address: philippe.brouqui@univ-amu.fr (P. Brouqui)

25 October 2017

23 December 2017 